\title{
Production of greenhouse gas free hydrogen by thermocatalytic decomposition of methane - A review
}

\author{
U.P.M. Ashik ${ }^{\text {a }}$, W.M.A. Wan Daud ${ }^{\mathrm{a}, *}$, Hazzim F. Abbas ${ }^{\mathrm{b}}$ \\ a Department of Chemical Engineering, University of Malaya, 50603 Kuala Lumpur, Malaysia \\ bepartment of Chemical Engineering, University of Nizwa, Al Dakulaya, Oman
}

\section{A R T I C L E I N F O}

\section{Article history:}

Received 10 June 2014 Received in revised form

1 December 2014

Accepted 12 December 2014

Available online 5 January 2015

Keywords:

Catalytic methane decomposition

Hydrogen production

Metal-carbon catalysts

Methane co-feeding

Hydrogen separation membrane
A B S T R A C T

Thermocatalytic decomposition of methane (TCD) is a fully green single step technology for producing hydrogen and nano-carbon. This review studying all development in laboratory-scale research on TCD, especially the recent advances like co-feeding effect and catalyst regeneration for augmenting the productivity of the whole process. Although a great success on the laboratory-scale has been fulfilled, TCD for greenhouse gas (GHG) free hydrogen production is still in its infancy. The need for commercialization of TCD is greater than ever in the present situation of huge GHG emission. TCD usually examined over various kind of catalysts, such as monometallic, bimetallic, trimetallic, combination of metal-metal oxide, carbonaceous and/or metal doped carbon catalysts. Deactivation of catalysts is the prime drawback found in TCD process. Catalyst regeneration and co-feeding of methane with other hydrocarbon are the two solutions put forwarded in accordance to overcome deactivation hurdle. Higher amount of co-feed hydrocarbon in situ produce more amount of highly active carbonaceous deposits which assist further methane decomposition to produce additional hydrogen to a great extent. The methane conversion rate increases with increase in the temperature and decreases with the flow rate in the co-feeding process in a similar manner as observed in normal TCD. The presence of co-components in the post-reaction stream is a key challenge tackled in the co-feeding and regeneration. Hence, this review hypothesizing the integration of hydrogen separation membrane in to methane decomposition reactor for online hydrogen separation.

Contents

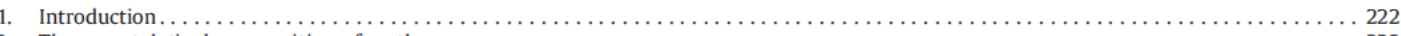

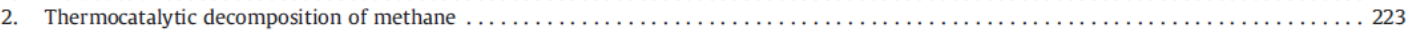

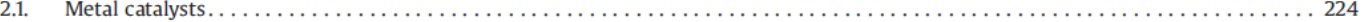

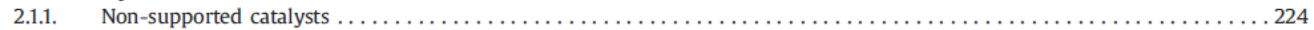

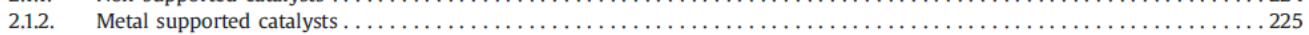

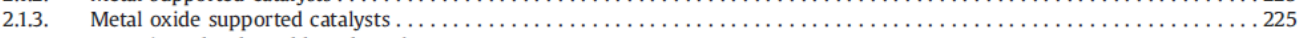

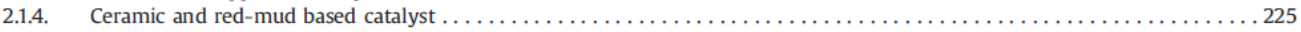

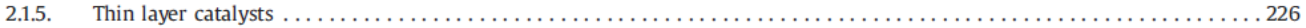

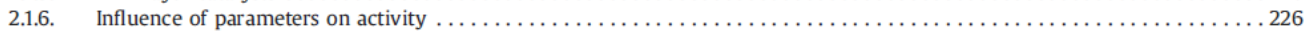

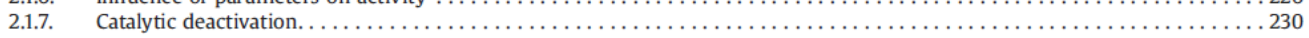

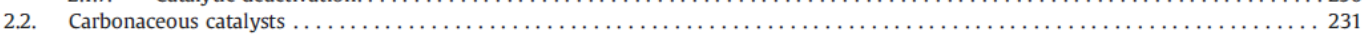

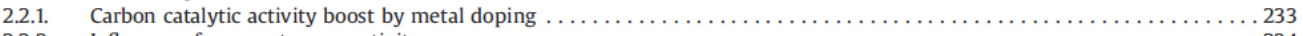

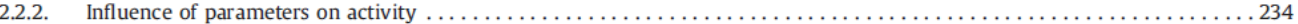

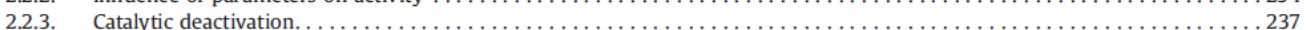

Abbreviations: TCD, thermocatalytic decomposition of methane; SRM, steam reforming of methane; POX, partial oxidation; DRM, dry reforming of methane; GHG, greenhouse gas; CNF, carbon nano-fibers; MSI, metal-support interaction; GHSV, gas hourly space velocity; TLC, thin layer catalysts; AC, activated carbon; CB, carbon black; ACPS, activated carbon from palm shell; CNT, carbon nano tube; NCB, nano-sized carbon black; CNF, carbon nano fiber; MWNT, multiwalled nanotube; CLR, coal liquefaction residue; HES, high-energy sites; HPC, hierarchical porous carbon; OSG, oxygen surface group; OCM, oxidative coupling of methane; DFT, density functional theory

Corresponding author. Tel.: +60 105023818; fax: +60 379675319 .

E-mail addresses: upmashik@gmail.com (U.P.M. Ashik), ashri@um.edu.my (W.M.A. Wan Daud), hazzim_f@yahoo.com (H.F. Abbas).

http://dx.doi.org/10.1016/j.rser.2014.12.025

1364-0321/o 2014 Elsevier Ltd. All rights reserved. 


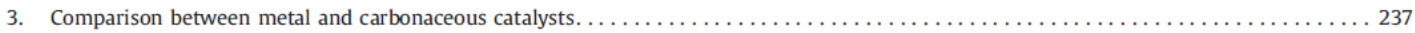

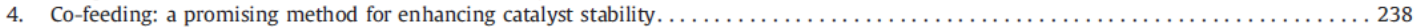

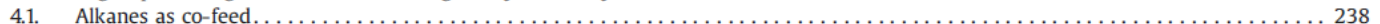

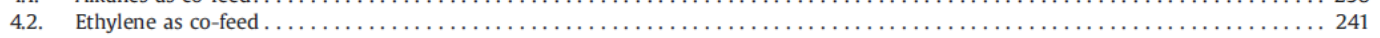

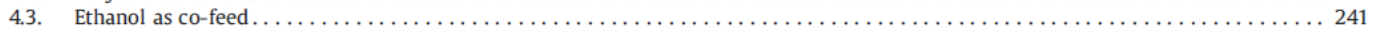

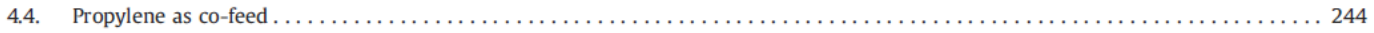

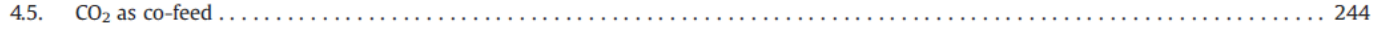

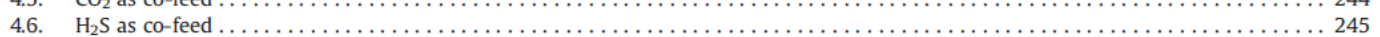

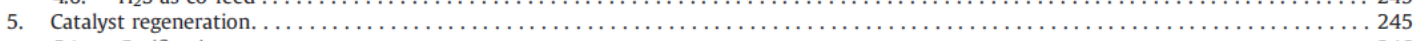

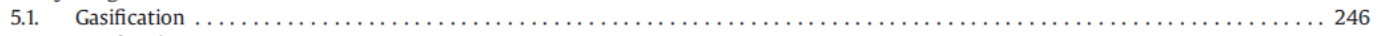

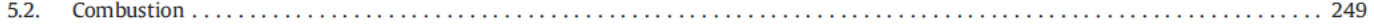

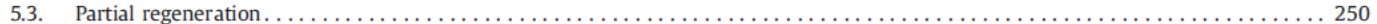

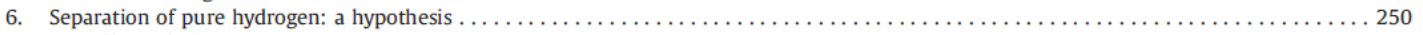

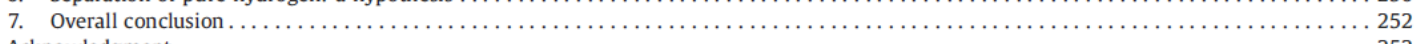

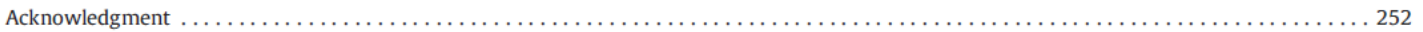

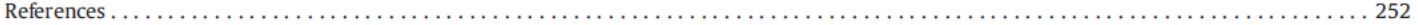

\section{Introduction}

Hydrogen, the simplest, the lightest and the most abundant element in the known universe appears to be one of the auspicious energy carriers, however, the greenest one if produced from renewable resources. This alternative green fuel is indispensable in the contemporary scenario of huge greenhouse gas (GHG) emission from the combustion of fossil fuel. Since, fossil fuels dominate energy consumption with a market share of $87 \%$, all the while, renewable energy accounts $2 \%$ only [1]. According to the International Energy Agency's World Energy Outlook 2012 [2], the global energy requirement expected to grow by more than onethird over the period 2035. The rise in energy consumption causes the elevation in the emission of GHGs like $\mathrm{CO}_{x}, \mathrm{C}_{x} \mathrm{H}_{y}, \mathrm{NO}_{x}, \mathrm{SO}_{x}$, etc. [3]. Consequently, atmospheric $\mathrm{CO}_{2}$ level hits awful record highs [4]. This increasing $\mathrm{CO}_{2}$ emissions will lead to anthropogenic global warming, climate change and ocean acidification, which would have severe consequences for ecosystem and for sustainability of human society. Moreover, fossil fuel is about to run out of availability soon as its limited reserve in earth. Hence, it is essential to place the worldwide energy system onto a more sustainable, secure and environmentally benign path. Unfortunately, sources like wind, solar, bio and nuclear are not desirable for economic energy production, because of their undeveloped technology, establishment cost and safety concerns. Hence, hydrogen being considered as a clean fuel as it produces water only on its combustion [5,6]. Furthermore, $\mathrm{H}_{2}-\mathrm{O}_{2}$ fuel cells are environmentally benign and highly efficient device which converts chemical energy of hydrogen directly into electricity. However, it overcomes the limitations imposed by the Carnot efficiency.

Hydrogen produces three times higher quantity of energy (39.4 $\mathrm{kWh} \mathrm{kg}^{-1}$ ) during its combustion than that produced by any other fuel on a mass basis, e.g. liquid hydrocarbons $\left(13.1 \mathrm{kWh} \mathrm{kg}^{-1}\right)$ [7]. Hence, one gallon of gasoline has about the same energy as one kilogram of hydrogen gas and it is expected that the hydrogen can replace all forms of fossil fuels in recent future. Approximately 100 times of the present hydrogen production (more than $3 \times 10^{12} \mathrm{~kg}$ ) would have to be produced per year to fulfill world's demand for fossil fuel. There is no natura resource of hydrogen and therefore it is not a primary fuel. Hence, hydrogen must be extracted at low cost from other abundant primary energy sources like coal, natural gas, naphtha, heavy oil, biomass, wastes, solar, wind, or nuclear power, without harming the environment [8-10]. Global statistics illustrate that $48 \%$ (240 Billion cubic meters $(\mathrm{Bcm}) / \mathrm{yr})$ of hydrogen is produced from natural gas (NG), 30\% (150 Bcm/yr) from petroleum, and $18 \%$ $(90 \mathrm{Bcm} / \mathrm{yr})$ from coal, while only $4 \%(20 \mathrm{Bcm} / \mathrm{yr})$ is obtained through water electrolysis [11]. The worldwide contribution of different sources to overall hydrogen production and its sector wise-usage are show in Fig. 1. The major contribution of NG for hydrogen production owe to the availability of huge methane reserves in deep ocean bed as well as in industrialized countries like United States [12].

Various hydrogen production method were developed, such as bio-hydrogen production, reviewed elsewhere [13], steam reforming of methane (SRM), partial oxidation (POX), coal gasification, water splitting, biomass gasification and thermochemical processes $[14,15]$. Water splitting process, consuming renewable solar and wind energy is very fascinating, but not economical because of its poor efficiency and higher processing cost. Water can be directly converted to $\mathrm{H}_{2}$ and $\mathrm{O}_{2}$ with zero $\mathrm{CO}_{2}$ emission by using photoelectrodes with sunlight illumination in aqueous electrolytes. The integration of solar energy concentration systems with systems capable to split water is of immense value and impact on the energetics and economics worldwide. For this application, the photoelectrode materials must have an appropriate band gap, special catalytic properties and needs to be stable in the aqueous environment under illumination [16]. Unfortunately, nearly all known materials today fail to fulfill these conditions [17]. The highest reported solar to hydrogen conversion efficiency till 1998 was $12.4 \%$ [16] for an illuminated area of $0.2 \mathrm{~cm}^{2}$, referring to the lower heat value of hydrogen. Peharz et al. [18], achieved an efficiency of $18 \%$ in 2007 for the solar to hydrogen production under outdoor conditions. The hydrogen production rate obtained with water splitting process is too low due to quick charge recombination of photo-generated electron/hole pairs, quick backward reaction and inability to utilize visible light efficiently [19]. Furthermore, the dissociation of water is a reaction not favoured thermodynamically; one has to go up to extremely high temperatures $\left(>2200^{\circ} \mathrm{C}\right)$ for obtaining some significant dissociation degree [20]. Moreover, direct one-step water splitting requires the energy intensive process of high temperature oxygen-hydrogen separation coupled with expensive membrane technology and therefore is considered of little chance for technical and economical viability in the near future. Additionally, gasification and reforming of biomass are extensively explored for producing hydrogen from several biomass resources such as forest residues, wood wastes, crop residues, waste water treatment, biogas, etc. [21]. Nevertheless, the major limitations of these technologies are the necessity of coupling of further stages like gas separation/ purification treatments and the occurrence of further sophisticated reactions which reduces hydrogen selectivity [22]. Fig. 2 depicting different sources, preparation methods, intensity of GHG emission of each process and utilization of hydrogen. 
a

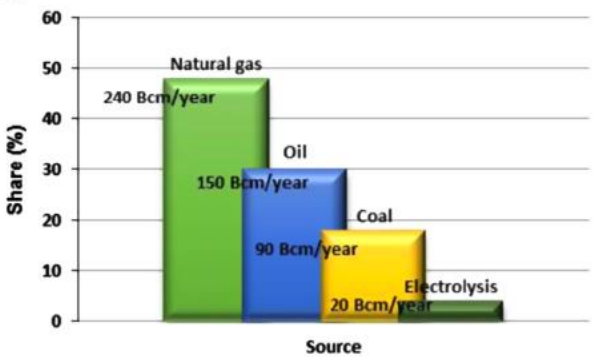

b

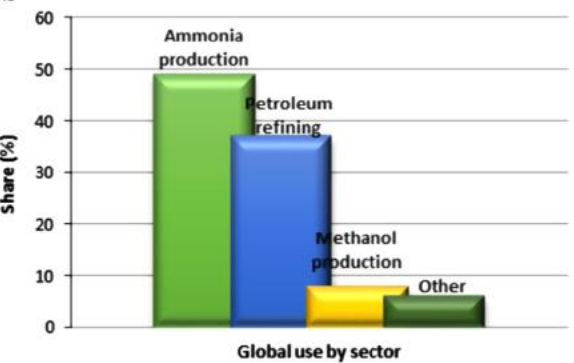

Fig. 1. (a) Worldwide hydrogen production by sources and (b) sector-wise usage of hydrogen.

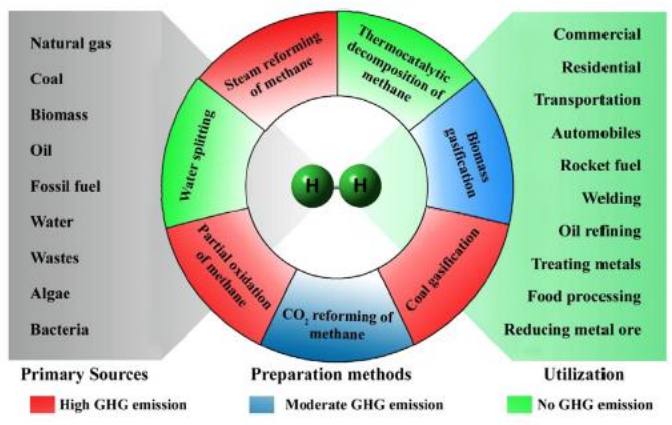

Fig. 2. Schematic representation of the sources, preparation methods and utilization of hydrogen.

SRM and POX are the current thermochemical processes for hydrogen production from methane, the main constituent of NG having highest C:H ratio. SRM has been considered as the one of the most common and regularly adopted technique for many years. In spite of its high process efficiency (50\%) and comparatively low cost, SRM causes high emissions of $\mathrm{CO}_{x}$ (at least $1 \mathrm{~mol}$ of $\mathrm{CO}_{2} / \mathrm{mol}$ of converted methane) and requires more process energy [23]. Moreover, fuel reforming process is multifaceted containing CO elimination by water gas shift reaction together with selective CO oxidation. Hence, the post-reaction mixture contains huge quantities of $\mathrm{CO}$ even after the purification. Similarly, the POX process is also causes GHG emission. Consequently, TCD or socalled methane cracking attracted as a novel technique for ecofriendly hydrogen production. In this moderately endothermic process, methane is thermally decomposed to solid carbon and gaseous hydrogen in a technically simple one step process as shown in Eq. (1).

$\mathrm{CH}_{4} \rightarrow \mathrm{C}+2 \mathrm{H}_{2} \quad \Delta H_{298 \mathrm{~K}}=74.52 \mathrm{~kJ} / \mathrm{mol}$

\section{Thermocatalytic decomposition of methane}

Thermocatalytic decomposition of methane (TCD), the most economical hydrogen production method, has been extensively studied since 1960s [24-28]. The prime benefit of TCD is the near elimination of GHG release [12]. Moreover, technically the hydrogen produced by TCD can directly use as the fuel for $\mathrm{H}_{2}-\mathrm{O}_{2}$ fuel cell as well as in internal combustion engine without further purification step, hence produced hydrogen is free from $\mathrm{CO}_{x}$ [23]. Furthermore, nano-carbon, of possible interest for a variety of potential further applications such as gas (e.g. hydrogen) storage [29], polymer additives [30], catalyst support or direct catalyst [31], is the co-product in TCD process. Despite the fact that hydrogen produced from methane cracking is a pure form of hydrogen, methane cracking is not used on an industrial scale for producing hydrogen since the technology is still in laboratory level. While, industrially emerged hydrogen production technologies were reviewed elsewhere [32].

Due to its very strong $\mathrm{C}-\mathrm{H}$ bond $(440 \mathrm{~kJ} / \mathrm{mol})$ and high symmetry of the molecular structure, methane is the one of the most inactive hydrocarbons, and its decomposition can only take place efficiently at a temperature higher than $1200{ }^{\circ} \mathrm{C}$ in the absence of a catalyst. Various metal and carbonaceous catalysts have been introduced in the interest of reducing decomposition temperature. In pursuance of producing $\mathrm{CO}_{2}$ free hydrogen, methane decomposition mechanism mainly involves five steps [33] as follows. (i) The chemisorption of methane on the leading face of a catalyst particle, (ii) detachment of a chemisorbed methane molecule through progressive breaking of four $\mathrm{C}-\mathrm{H}$ bonds as follows:

$\left(\mathrm{CH}_{4}\right)_{\mathrm{g}} \rightarrow\left(\mathrm{CH}_{3}\right)_{\mathrm{a}}+(\mathrm{H})_{\mathrm{a}}$

This step is followed by a series of surface stepwise dissociation reactions leading to elemental carbon and hydrogen [34]:

$\left(\mathrm{CH}_{3-x}\right)_{\mathrm{a}} \rightarrow\left(\mathrm{CH}_{2-x}\right)_{\mathrm{a}}+(\mathrm{H})_{\mathrm{a}}$

where $0<x<2$; subscripts (a), (c) and (g) denote adsorbed, crystalline and gaseous species, respectively. (iii) Aggregation of adsorbed atomic hydrogen into molecules, followed by gas phase emission,

$2(\mathrm{H})_{\mathrm{a}} \rightarrow\left(\mathrm{H}_{2}\right)_{\mathrm{g}}$

(iv) atomic carbon aggregation into encapsulated carbon, leading to progressive catalyst deactivation, or atomic carbon diffusion through the bulk catalyst from the leading face to the trailing face, driven by the existing pronounced concentration gradient, and (v) carbon nucleation followed by the formation and growth of carbon nano-fibers (CNFs) in the trailing face of the catalyst particle.

$(C)_{a} \rightarrow 1 / n\left(C_{n}\right)_{c}$ (Carbon crystalline growth)

The kinetic laws (pre-exponential factor, activation energy and reaction order) of each intermediate elementary reaction step are still unknown [35]. TCD process has less environmental impact compared to commercial hydrogen production method like SRM. Even though, TCD process is facing many challenges as follows: catalytic deactivation, presence of unreacted methane in out stream, possibility of further components in case of co-feed assisted methane decomposition and formation of $\mathrm{CO}_{\mathrm{x}}$ during 
regeneration of deactivated catalyst. All these titles are discussed in details in this review. This segment of review discusses various metal and carbon based catalyst briefly, giving special importance to the recently developed catalysts.

\subsection{Metal catalysts}

Over the past few decades, many efforts have been devoted for developing simple and efficient synthesis protocols for the preparation of suitable catalyst in order to realize the TCD process with a moderate condition. Various metal catalysts [36-39], different supports and numerous carbonaceous catalysts have been studied extensively [40-42]. In addition to hydrogen, ordered nanocarbons are forming with metal catalyst, while carbonaceous catalysts produce amorphous carbon having a variety of morphology $[43,44]$. The general reaction mechanism on different meta catalysts has been supposed to be similar. However, the chemical composition and preparation method, the support and promoter influence the activity and stability of catalyst and determine the structure and morphology of the carbon formed. Catalytic activity and stability of various kind of catalysts are compared in Table 1 , which comprises the conserved stability, activity and maximum methane conversion or hydrogen production of various metal catalysts had already been studied.

\subsubsection{Non-supported catalysts}

It has been reported that the rate of methane decomposition of non-supported metal catalysts are in the order of $\mathrm{Ni}, \mathrm{Co}, \mathrm{Ru}$, $\mathrm{Rh}>\mathrm{Pt}, \mathrm{Re}, \mathrm{Ir}>\mathrm{Pd}, \mathrm{Cu}, \mathrm{W}, \mathrm{Fe}, \mathrm{Mo}$ [67]. Among them, Ni, Co and Fe catalyst gained major attention because of their advantages like availability, low cost, better activity and stability $[47,50]$. Ni crystal size has immense influence on the methane decomposition and carbon formation. Its direct relationship with coking threshold (thermodynamic equilibrium constant) was revealed in 1975 [68] Rapid aggregation and carbon encapsulation deactivate nonsupported Ni-catalyst rapidly, especially at a temperature highe than $600{ }^{\circ} \mathrm{C}$ [57]. However, theoretical thermodynamic equilibrium study were evaluated by using a commercial Outokumpu HSC Chemistry 5.11 chemical equilibrium calculation software illustrated that methane conversion is thermodynamically inadequate at this temperature $[69,70]$, resulting to a low hydrogen yield [50]. On the other hand, despite showing hasty deactivation on continuous cycles directing short life time, Fe catalysts have more stability at higher temperature range of $700-1000{ }^{\circ} \mathrm{C}[71]$.

Table

Catalytic activity and stability of various catalysts recently studied.

\begin{tabular}{|c|c|c|c|c|c|c|c|}
\hline \multirow[t]{2}{*}{ Catalyst } & \multirow[t]{2}{*}{$w$} & \multicolumn{2}{|c|}{ Stability and activity maintained } & \multirow{2}{*}{$\begin{array}{l}\text { Max. } \mathrm{CH}_{4} \text { conversion } \\
\text { at } t, T \text { and } F\end{array}$} & \multirow[t]{2}{*}{ Max. $\mathrm{H}_{2}$ produced } & \multirow[t]{2}{*}{$t / T / F$} & \multirow[t]{2}{*}{ Ref. } \\
\hline & & $T$ & $t$ & & & & \\
\hline $\mathrm{Ni}$ & 0.04 & 650 & 130 & 35 & - & $0 / 650 / 45,000^{\mathrm{a}}$ & [45] \\
\hline $\mathrm{Ni}$ & 0.04 & 500 & 37 & 9 & - & $0 / 500 / 60^{\mathrm{b}}$ & [46] \\
\hline $\mathrm{Fe}$ & 2 & 900 & $>75$ & 98 & - & $14 / 800 / 20^{\mathrm{b}}$ & [12] \\
\hline $\mathrm{Ni}-\mathrm{Cu}$ & 1 & 900 & 5 & 96 & - & $0.5 / 900 / 110^{c}$ & [47] \\
\hline $\mathrm{Fe}-\mathrm{Cu}$ & 0.75 & 600 & 5 & 51 & - & $1.6 / 600 / 110^{c}$ & [48] \\
\hline $\mathrm{Ni}-\mathrm{Cu}-\mathrm{Al}$ & 0.05 & 800 & 2.75 & - & 75 & $0.5 / 700 / 120,000^{\mathrm{a}}$ & [33] \\
\hline Ni/Ce-MCM-41 & 0.05 & 580 & $>23$ & 75 & - & $18 / 580 / 75^{\mathrm{b}}$ & [49] \\
\hline $\mathrm{Ni}-\mathrm{Cu}-\mathrm{Zn} / \mathrm{MCM}-22$ & 1 & 800 & $>50$ & 85 & - & $0 / 750 / 10^{\mathrm{b}}$ & [24] \\
\hline $\mathrm{Ni} / \mathrm{SiO}_{2}$ & 0.15 & 600 & $>10$ & 22 & - & $0 / 600 /-$ & [50] \\
\hline $\mathrm{Ni} / \mathrm{SiO}_{2}$ & 0.03 & 650 & 4 & 42 & - & $0 / 650 / 15^{\mathrm{b}}$ & [51] \\
\hline $\mathrm{Ni} / \mathrm{TiO}_{2}$ & 0.3 & 700 & 8 & - & 73 & $0.1 / 700 / 20^{b}$ & [52] \\
\hline $\mathrm{Ni} / \mathrm{Al}_{2} \mathrm{O}_{3}$ & - & 700 & 3 & - & 73 & $0 / 700 / 12^{\mathrm{a}}$ & [53] \\
\hline $\mathrm{Ni} / \mathrm{La}_{2} \mathrm{O}_{3}$ & 0.53 & 600 & 5 & 75 & - & $1 / 600 / 110^{c}$ & [54] \\
\hline $\mathrm{Fe} / \mathrm{Al}_{2} \mathrm{O}_{3}$ & - & 800 & 3 & - & 91 & $0.4 / 800 / 1.5^{\mathrm{a}}$ & [53] \\
\hline $\mathrm{Fe} / \mathrm{Al}_{2} \mathrm{O}_{3}$ & 0.02 & 900 & 6 & 68 & - & $0 / 900 / 6000^{\mathrm{a}}$ & [55] \\
\hline $\mathrm{Fe} / \mathrm{MgO}$ & 0.15 & 800 & 3 & - & 55 & $0 / 800 / 12,000^{\mathrm{a}}$ & [56] \\
\hline $\mathrm{NiCu} / \mathrm{Al}_{2} \mathrm{O}_{3}$ & 10 & 750 & $>7$ & - & 80 & $0 / 750 / 12,000^{\mathrm{a}}$ & [28] \\
\hline $\mathrm{Ni}-\mathrm{Ca} / \mathrm{SiO}_{2}$ & 0.05 & 580 & 3 & 39 & - & $0 / 580 / 100^{\mathrm{b}}$ & [57] \\
\hline $\mathrm{Ni}-\mathrm{K} / \mathrm{SiO}_{2}$ & 0.05 & 580 & 3 & 40 & - & $0 / 580 / 100^{\mathrm{b}}$ & [57] \\
\hline $\mathrm{Ni}-\mathrm{Ce} / \mathrm{SiO}_{2}$ & 0.05 & 580 & 3 & 90 & - & $0 / 580 / 100^{\mathrm{b}}$ & [57] \\
\hline $\mathrm{Ni}-\mathrm{Fe} / \mathrm{SiO}_{2}$ & 0.03 & 650 & $>4$ & 46 & - & $0 / 650 / 15^{\mathrm{b}}$ & [51] \\
\hline $\mathrm{Ni}-\mathrm{Cu} / \mathrm{SiO}_{2}$ & 1 & 750 & 45 & 88 & 86 & $5 / 750 / 1800^{a}$ & [58] \\
\hline $\mathrm{Ni}-\mathrm{Cu}-\mathrm{TiO}_{2}$ & 0.3 & 700 & 8 & - & 80 & $0 / 700 / 20^{\mathrm{b}}$ & [52] \\
\hline $\mathrm{Ni}-\mathrm{Cu} / \mathrm{MgO}$ & - & 700 & 3 & - & 79 & $0.75 / 700 / 12^{\mathrm{a}}$ & [53] \\
\hline $\mathrm{Ni} / \mathrm{MgAl}_{2} \mathrm{O}_{4}$ & 0.1 & 700 & 5 & 37 & - & $1 / 550 / 80^{\mathrm{b}}$ & [59] \\
\hline $\mathrm{Ni}-\mathrm{Cu} / \mathrm{La}_{2} \mathrm{O}_{3}$ & 0.53 & 900 & $>26$ & 97 & - & $0 / 900 / 110^{c}$ & [54] \\
\hline $\mathrm{Ni} / \mathrm{Ce}-\mathrm{SiO}_{2}$ & 0.2 & 600 & 2 & 50 & - & $0.3 / 600 / 100^{\mathrm{b}}$ & [60] \\
\hline $\mathrm{Fe}-\mathrm{Mo} / \mathrm{MgO}$ & - & 800 & 3 & - & 92 & $0 / 700 / 1.5^{\mathrm{a}}$ & [53] \\
\hline $\mathrm{FeMo} / \mathrm{MgO}$ & 0.15 & 950 & 3 & - & 96 & $0.3 / 950 / 1000^{\mathrm{a}}$ & [56] \\
\hline $\mathrm{FeMo} / \mathrm{Al}_{2} \mathrm{O}_{3}$ & 0.15 & 800 & 3 & - & 88 & $0 / 800 / 12000^{a}$ & [56] \\
\hline $\mathrm{Co} / \mathrm{Ce}-\mathrm{TiO}_{2}$ & 0.2 & 500 & 2 & 5 & - & $1.9 / 500 / 100^{\mathrm{b}}$ & [60] \\
\hline $\mathrm{Co} / \mathrm{Al}_{2} \mathrm{O}_{3} / \mathrm{SiO}_{2}$ & - & 700 & 30 & 90 & - & $0 / 700 / 1900 \mathrm{~h}^{-1}$ & [61] \\
\hline $\mathrm{CoO}-\mathrm{MoO} / \mathrm{Al}_{2} \mathrm{O}_{3}$ & 0.4 & 700 & 2 & 78.9 & - & $0 / 700 / 250^{\mathrm{b}}$ & [62] \\
\hline $\mathrm{Pt}-\mathrm{Ni} / \mathrm{MgAl}_{2} \mathrm{O}_{4}$ & 0.1 & 700 & 4 & 45 & - & $0 / 700 / 80^{\mathrm{b}}$ & [63] \\
\hline $\mathrm{MgO} / \mathrm{SiO}_{2}$ & - & 900 & 200 & - & 45 & $0 / 750 / 60-65^{\mathrm{b}}$ & [64] \\
\hline $\mathrm{K} / \mathrm{MgO} / \mathrm{SiO}_{2}$ & - & 900 & 200 & - & 77 & $0 / 800 / 60-65^{b}$ & [64] \\
\hline $\mathrm{Ni} / \mathrm{K} / \mathrm{MgO} / \mathrm{SiO}_{2}$ & - & 900 & 200 & - & 61 & $0 / 700 / 60-65^{\mathrm{b}}$ & [64] \\
\hline $\mathrm{LaNiO}_{3}$ perovskite & 0.05 & 700 & 4 & 81 & - & $1.2 / 700 / 15^{\mathrm{b}}$ & [65] \\
\hline $\mathrm{LaNiO}_{3}$ perovskite & - & 800 & 5 & 91 & - & $0.5 / 800 / 20^{\mathrm{b}}$ & {$[66]$} \\
\hline $\mathrm{NiO} / \mathrm{La}_{2} \mathrm{O}_{3}$ & - & 800 & 5 & 93 & - & $0 / 800 / 20^{\mathrm{b}}$ & {$[66]$} \\
\hline
\end{tabular}

$\left(W=\right.$ weight $(\mathrm{g}), T=$ temperature $\left({ }^{\circ} \mathrm{C}\right) ; t=$ time $(\mathrm{h}) ; F=$ flow rate $\left({ }^{\mathrm{a}} \mathrm{mL} /\left(\mathrm{g}_{\text {cat. }} \mathrm{h}\right){ }^{\mathrm{b}} \mathrm{mL} / \mathrm{min}{ }^{\mathrm{c}} \mathrm{NmL} / \mathrm{min}\right.$, unless other units are stated); conversion (\%); - , not mentioned in the original paper). 
Moreover, Fe-based catalysts produce thin wall carbon nanotubes as byproduct, which are invaluable among nanocarbons [72]. Hence, most of the Fe-based catalyst work have devoted for the production of nanocarbon other than hydrogen production. Therefore, those works are excluded from this review as it is focusing on hydrogen production. While, cobalt catalyst did not get as much attention as $\mathrm{Ni}$ and $\mathrm{Fe}$ catalysts. Partially filled 3d orbitals of $\mathrm{Fe}, \mathrm{Co}$ and $\mathrm{Ni}$ facilitate the dissociation of the hydrocarbon molecules through partially accepting electrons. This interaction along with "back-donation" from the metal into the unoccupied orbital in the hydrocarbon molecule changes the electronic structure of the adsorbed molecule so that the dissociation of the molecule occurs [73]. While, copper, a non-transition metal with its 3d shell completely filled, was observed to yield very less hydrogen and amorphous carbon. Likewise, noble metals (Rh, Ru and Pt) do not provide heartening results in terms of methane conversion in TCD [69]. The main advantage of non-supported catalyst is the magnetic properties associated with those materials which facilitate the recovery of the catalyst after the reaction, once the latter is mixed with the produced carbon $[69,74]$.

\subsubsection{Metal supported catalysts}

The metal-supported catalyst belongs to the heterogeneous catalysis. The metal would be polarized by the influence of charge enclosed in the support [75], which make changes in their properties. Strong Metal-Support Interaction (MSI) increases the dispersion of metal by decreasing its mobility. MSI can make changes on the crystallography and the electronic state of the metal particles depending on the intensity of the interaction [76]. The factors influencing the catalytic activity are the electronic state of the metal particles, crystalline size, dispersion of metal particles, textural properties, pore geometry of the support [77], catalyst composition [28], catalyst preparation method [78], and catalyst rinsing solvent [46]. Numbers of efforts have been devoted in favor of improving catalytic activity and stability by bringing changes in the above mentioned factors.

Various types of metal supported catalysts like $\mathrm{Ni}-\mathrm{Cu}[24,79]$, $\mathrm{Ni}-\mathrm{Zn}$ [80], $\mathrm{Fe}-\mathrm{Pd}, \mathrm{Fe}-\mathrm{Mo}, \mathrm{Fe}-\mathrm{Ni}[26]$ and $\mathrm{Ni} / \mathrm{Cu} / \mathrm{Al}$ [81] had been introduced in order to improve the activity. Addition of $\mathrm{Cu}$ in to $\mathrm{Ni}$ and Fe by in situ thermal treatment has immense enhancement on their catalytic activity and stability. $\mathrm{Ni}-\mathrm{Cu}$ catalyst shows catalytic stability up to $700-750{ }^{\circ} \mathrm{C}$ with a $70-85 \%$ methane conversion $[47,80]$. There is no significant catalytic deactivation occurred for $300 \mathrm{~min}$. Cu doped Ni produces octopus and porous CNF with high surface area. Similarly, $\mathrm{Cu}$ addition in to $\mathrm{Fe}$ improves with $51 \%$ methane conversion with better life span than monometallic $\mathrm{Fe}$ catalyst [48]. This higher stability and activity of supported catalysts explained in terms of ensemble effect, which decreases the rate of formation of encapsulating carbon. Furthermore, Density functional theory (DFT) calculations show that $\mathrm{Cu}-\mathrm{W}$ and $\mathrm{Cu}-\mathrm{Mo}$ composite particles have binding energies in the same range as $\mathrm{Fe}, \mathrm{Co}$ and $\mathrm{Ni}$. The addition of a dopant to $\mathrm{Cu}$ in an appropriate ratio modifies the binding energy into a certain range suitable for $\mathrm{C}-\mathrm{H}$ bond cleavage formation [82,83]. Moreover, $\mathrm{Fe}$ gives better results while coupling with $\mathrm{Mg}, \mathrm{Co}, \mathrm{Pd}, \mathrm{Ni}$, and $\mathrm{Mo}$ than monometallic Fe at $700-800{ }^{\circ} \mathrm{C}[26,84,85]$.

\subsubsection{Metal oxide supported catalysts}

Metal supported on metal oxide catalysts $\left(\mathrm{Co} / \mathrm{Mo} / \mathrm{Al}_{2} \mathrm{O}_{3}[62,86]\right.$, $\mathrm{Ni}-\mathrm{Cu} / \mathrm{SiO}_{2}$ [58], $\mathrm{Ni}-\mathrm{Cu} / \mathrm{Al}_{2} \mathrm{O}_{3}[28], \mathrm{Mo}-\mathrm{Fe} / \mathrm{Al}_{2} \mathrm{O}_{3}$ [87]) have gained tremendous attention as they exhibit high catalytic activity and stability for TCD process. However, the methodology for selecting the third component is not systematically illustrated until now. It is reported that oxide support can alter the surface chemistry of metal catalyst particles through epitaxial, spillover, and migration effects [75]. Lee et al. [62] conduct TCD over $\mathrm{CoO}-\mathrm{MoO} / \mathrm{Al}_{2} \mathrm{O}_{3}$ and found the initial methane conversions are 50.8, 65.5, 71.6, and $78.9 \%$ over the catalyst with $10,20,30$ and 40 wt\% CoO-MoO loading, respectively. It shows a gradual increase in initial methane conversion with metal loading. In a broad-spectrum, the examined operating temperatures for Ni-based catalysts are ranged from 500 to $900{ }^{\circ} \mathrm{C}$ with the highest methane conversion of $85 \%$ at $750{ }^{\circ} \mathrm{C}$, while that for Fe-based catalysts are $200-1200{ }^{\circ} \mathrm{C}$ with $>90 \%$ methane conversion at $800^{\circ} \mathrm{C}[12,53,80]$. In 1998, Muradov [88] generated $\mathrm{CO}_{2}$ free hydrogen yield very close to the equilibrium value with $\mathrm{Fe}_{2} \mathrm{O}_{3}$ catalysts at $850{ }^{\circ} \mathrm{C}$. $\mathrm{Fe}-\mathrm{Mo} / \mathrm{MgO}$ [56] withstands temperature up to $950{ }^{\circ} \mathrm{C}$ with methane conversion of higher than $90 \%$ for $3 \mathrm{~h}$ continuously. $\mathrm{Fe} / \mathrm{Al}_{2} \mathrm{O}_{3}[55]$ also shows better performance at higher temperature. In spite of having better stability at higher temperature range, the overall performance of the Fe-based catalysts is not as good as that of Ni-based catalysts. It paved the way to introduce Fe incorporated Ni-based catalysts. The addition of $\mathrm{Fe}$ in to $\mathrm{Ni} / \mathrm{SiO}_{2}$ catalysts boost up its activity by about 3 times without much deactivation [51]. The addition of $\mathrm{Cu}$ and $\mathrm{Zn}$ in to Ni-based catalysts enhance the catalytic stability up to $800{ }^{\circ} \mathrm{C}$ with $72 \%$ methane conversion [24]. Ni-Cu- $\mathrm{SiO}_{2}$ (50:10:40) shows higher activity with a maximum methane conversion of $88 \%$ corresponding to a hydrogen yield of $86 \%$ at a temperature $750{ }^{\circ} \mathrm{C}$ and GHSV $1800 \mathrm{~mL} / \mathrm{h} \mathrm{gat}_{\text {cat }}$ [58]. $10 \% \mathrm{Cu}$ loading shows maximum activity, but further addition of $\mathrm{Cu}$ lower the activity and stability, especially at high temperature, as the higher amount of $\mathrm{Cu}$ make the catalyst particles easily in quasi-liquid state. The addition of $\mathrm{Ce}$ enhances the stability of both $\mathrm{Ni}$ and Fe-based catalyst by more than 10 times of that of $\mathrm{Ni} / \mathrm{SiO}_{2}$ catalyst $[49,60,89]$. It is attributed to the conversion of formed carbon to $\mathrm{CO}_{x}$ because of $\mathrm{Ce}^{4+} / \mathrm{Ce}^{3+}$ mechanism [49]. Hence, a small amount of $\mathrm{CO}_{x}$ has been detected throughout the experiments.

\subsubsection{Ceramic and red-mud based catalyst}

Ceramic materials have high melting point, high resistant to chemical attack, good mechanical strength, low acidity, good interaction with metallic phase [59], and do not form metal carbide [64]. All these properties are desirable for a catalyst support. Furthermore, unlike metal catalyst, ceramic catalyst can govern the reaction for producing specific product is it's additional advantage [64]. As expected, $\mathrm{Ni} / \mathrm{MgAl}_{2} \mathrm{O}_{4}$ illustrate better activity with $37 \%$ methane conversion for $1 \mathrm{~h}$ without much deactivation [59]. The contact time of reactant molecules was extremely important for methane decomposition and MgO have the affinity for sustaining hydrogen which was bonded to methane, in this way it increased the sustain time of methane on the ceramic surface, which was responsible for decomposition of methane. However, addition of Pt to the above mentioned ceramic support did not favor catalytic result [63]. Addition of $\mathrm{K}$ in to $\mathrm{MgO} / \mathrm{SiO}_{2}$ ceramic catalyst increases its activity to produce $77 \%$ maximum hydrogen yield and stability up to $900{ }^{\circ} \mathrm{C}$ even after $200 \mathrm{~h}$ [64]. Doping of $\mathrm{K}$ provides greater active sites and surface area to the catalyst for better decomposition and higher stability. However, $\mathrm{K}$ addition inhibited coke formation and carbon deposition during the decomposition reaction and hence did not suffer fast deactivation. Silica reacted with potassium oxide to form stable silicates which was actually responsible for the stability of ceramic materials for better active life $[90,91]$. Ceramic catalysts produces multiwalled carbon nanotubes which approximately same at optimize temperatures of $\mathrm{Ni}$ catalyst. No impurities were detected in nanotubes produced from cracking of methane from ceramics [64].

Red mud is a waste product of the aluminum industry. It is composed of iron oxides/oxyhydroxides/hydroxide, aluminum oxide/oxyhydroxide/hydroxide, silica, titania and a range of alkali and alkaline earth metal compounds such as sodium oxide and 
calcium oxide [92]. Of these, the iron compounds are generally the major phase constituents. Balakrishnan et al. [92] considered methane itself as a reductant and conduct methane decomposition over red-mud without any prior reduction step. Red-mud containing relatively high content of titanium seems to have reduced activity for methane conversion compared to a sample containing a comparable proportion of iron. The maximum hydrogen formation rate observed, $3.80 \times 10^{-5} \mathrm{~mol}_{\mathrm{H} 2} / \mathrm{g} \mathrm{s}$, was associated with a sample containing the highest proportion of iron and a lower concentration of alkali metal [92]. Elsewhere, alkali metals have been reported to be very effective poisons for the methane decomposition reaction [93]. The efficacy of the red mud samples is variable, which is related to differences in their composition which in turn reflects the purity of the bauxite ores from which they are produced. Advanced studies on red mud catalyst has yet to be conducted.

\subsubsection{Thin layer catalysts}

Thin layer catalysts (TLCs) are recently attracted the attention of investigators [61,94]. Frusteri et al. [94] found that the $\mathrm{Ni}$ and $\mathrm{Co}$ TLC supported on $\mathrm{Al}_{2} \mathrm{O}_{3}$ samples suitable for a cyclic dual-step process, which is comprised of TCD and catalyst regeneration by oxygen without damaging the catalyst. Furthermore, both $\mathrm{Ni}$ and Co exhibit a strong interaction with $\mathrm{Al}_{2} \mathrm{O}_{3}$ support surface and it is noticed that the formation of encapsulating carbon is depressed and only filamentous carbon forms. Despite of this advantage, $\mathrm{Ni}$ and Co silica supported catalyst were not found apt for long time catalysis as their deactivation by time. In fact, $\mathrm{Co} / \mathrm{Al}_{2} \mathrm{O}_{3} /$ Silica TLC is stable up to $700{ }^{\circ} \mathrm{C}$ for $32 \mathrm{~h}$ and convert more than $80 \%$ methane to hydrogen [61]. Cobalt particles strongly adsorb on $\mathrm{Al}_{2} \mathrm{O}_{3}$ support giving rise to the formation of $\mathrm{CoAl}_{2} \mathrm{O}_{4}$-type structures, which ensure an elevated metal dispersion inhibiting also the occurrence of sintering phenomena $[95,96]$. Irrespective of Co loading, initial hydrogen production increases with reaction temperature, while the relation between lifetime and activity of TLC catalyst with other operating parameters or catalyst characteristics have yet to be optimized. It is found that, $20 \%$ Co ensures both long lifetime and high hydrogen productivity.

\subsubsection{Influence of parameters on activity}

Catalyst stability and activity depends on the experimenta parameters such as reaction temperature, partial pressure, space velocity, etc. [97]. In general, the hydrogen content in the initia output of TCD process with metal catalysts is incredibly high, bu their activity decreases very fast with time. It is clear from

a

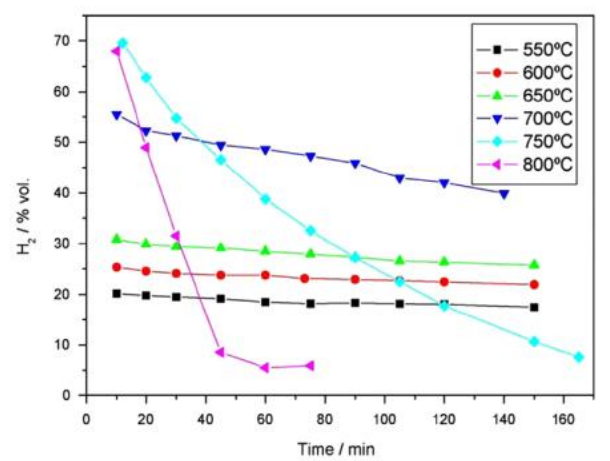

exploited metal catalysts that the activity increase as increasing the temperature up to a particular level then deactivation of catalyst starts $[24,28,45,49]$. NiCuAl catalyst has maintained its initial activity at low reaction temperatures, that is, 550, 600 and $650{ }^{\circ} \mathrm{C}$, with low hydrogen production of 20,26 and $31 \mathrm{vol} \%$, respectively, were measured in the outlet gas [33]. On the other hand, the initial hydrogen concentrations were much higher, 55 , 67 and $70 \mathrm{vol} \%$ at 700,750 and $800{ }^{\circ} \mathrm{C}$, respectively (Fig. 3a) However, the evolving hydrogen concentrations dropped quickly, indicating rapid catalyst deactivation. This effect was more evident as reaction temperature increased. This rapid deactivation of catalyst at higher temperature is attributed to the metal particle sintering and the formation of more ordered carbon. In a kinetic point of view, temperature and pressure are the main parameters

Table 2

The activation energy of the TCD process reported in literature over different catalysts.

\begin{tabular}{lll}
\hline Catalyst & Ea $(\mathrm{k} / \mathrm{mol})$ & Ref. \\
\hline $\mathrm{Ni}$ & 65.4 & {$[98]$} \\
$\mathrm{Ni}$ & 59 & {$[104]$} \\
$\mathrm{Ni}$ & 59 & {$[27]$} \\
$\mathrm{Ni}(111)$ & 53.9 & {$[107]$} \\
$\mathrm{Ni}-\mathrm{Al}$ & 64.6 & {$[100]$} \\
$\mathrm{Ni} / \mathrm{SiO}_{2}$ & 29.5 & {$[102]$} \\
$\mathrm{Ni}-\mathrm{Co}_{2}-\mathrm{Cu}$ & 67.5 & {$[98]$} \\
$\mathrm{Ni} / \mathrm{SiO}_{2}$ & 90 & {$[106]$} \\
$\mathrm{Ni} / \mathrm{TiO}_{2}$ & 60 & {$[101]$} \\
$\mathrm{Ni} / \mathrm{Zeolite}$ & 61.77 & {$[97]$} \\
$\mathrm{Ni}-\mathrm{Cu}_{2} / \mathrm{MgO}$ & 50.4 & {$[103]$} \\
$\mathrm{Ni} / \mathrm{Al}_{2} \mathrm{O}_{3}-\mathrm{CaO}$ & 88 & {$[105]$} \\
\hline
\end{tabular}

Table 3

Summary of the main parameter obtained in the experiments at different temperature over NiCuAl catalyst (WHSV:120 $\lg _{\text {cat }}^{-1} \mathrm{~h}^{-1}$ ) [33].

\begin{tabular}{|c|c|c|c|c|c|}
\hline$T\left({ }^{\circ} \mathrm{C}\right)$ & $\begin{array}{l}\mathrm{rCH}_{4,0} \\
\left(\mathrm{mmol} / \mathrm{min} \mathrm{g}_{\mathrm{cat}}\right)\end{array}$ & $\left(X_{\mathrm{CH} 4}\right)_{\mathrm{eq}}(\%)$ & $X_{\mathrm{CH}}(\%)$ & $\begin{array}{l}C_{\text {dep }} \\
\left(\mathrm{g} / \mathrm{g}_{\text {cat }}\right)\end{array}$ & $r_{\mathrm{C}}\left(\mathrm{g}_{\mathrm{c}} / \mathrm{g}_{\mathrm{cat}} \mathrm{h}\right)$ \\
\hline 550 & 10.02 & 34 & 10.20 & 16.4 & 6.56 \\
\hline 600 & 12.96 & 52.1 & 13.19 & 21.3 & 8.51 \\
\hline 650 & 16.25 & 64.2 & 16.17 & 26 & 10.40 \\
\hline 700 & 34.27 & 79.3 & 31.20 & 46.8 & 20.03 \\
\hline 750 & 47.60 & 85 & 22.06 & 39 & 14.18 \\
\hline 800 & 45.95 & 91.5 & 19.41 & 15.6 & 16.22 \\
\hline
\end{tabular}

b

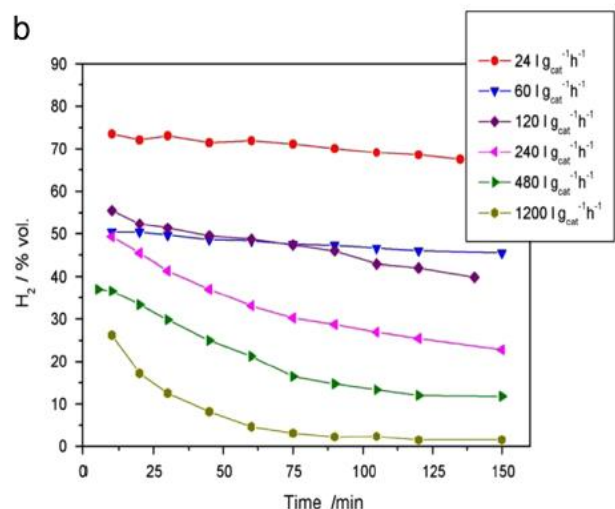

Fig. 3. (a) Influence of reaction temperature on the evolution of hydrogen concentration at space velocity $120 \mathrm{lg}^{-1} \mathrm{cat}^{-1}$. (b) influence of space velocity on the evolution of hydrogen concentration at temperature $700^{\circ} \mathrm{C}[33]$. 
influencing hydrogen formation rate over time. Kinetic studies are chemical stages conducted for developing a suitable model which describes the rate of reaction and defines the chemical process [98]. Recent studies [99] have shown that the initial $\mathrm{C}-\mathrm{H}$ bond breaking of $\mathrm{CH}_{4}$ is the rate determining step over the metal

Table 4

Summary of the main parameter obtained in the experiments at different space velocity over NiCuAl catalyst $\left(T: 700^{\circ} \mathrm{C}\right)[33]$.

\begin{tabular}{ccccc}
\hline $\begin{array}{c}\text { WHSV } \\
\left(\mathbf{l g}_{\text {cat }}^{-1} \mathbf{h}^{-1}\right)\end{array}$ & $\boldsymbol{r}_{\mathbf{0}}$ (mmol/min.g cat $)$ & $\boldsymbol{X}_{\mathbf{C H} \mathbf{4}}(\%)$ & $\boldsymbol{c}_{\text {dep }}\left(\mathrm{g} / \mathrm{g}_{\text {cat }}\right)$ & $\boldsymbol{r}_{\mathbf{C}}\left(\mathrm{g}_{\mathrm{d}} / \mathrm{g}_{\mathbf{c a t}} \cdot \mathbf{h}\right)$ \\
\hline 24 & 10.38 & 54.61 & 45.8 & \\
60 & 15.01 & 31.36 & 39 & 7.02 \\
120 & 34.27 & 31.2 & 46.8 & 20.06 \\
240 & 58.31 & 20.09 & 64.6 & 25.84 \\
480 & 79.95 & 11.63 & $84^{\mathrm{a}}$ & 33.60 \\
1200 & 134.74 & 8.77 & $141^{\mathrm{a}}$ & 56.40 \\
\hline
\end{tabular}

${ }^{\text {a }}$ Catalyst deactivated. catalyst at high temperatures, although the activation energy for $\mathrm{CH}_{4}$-bond dissociation decreased from $440 \mathrm{~kJ} / \mathrm{mol}$ in the gas phase to $65 \mathrm{~kJ} / \mathrm{mol}$ on a $\mathrm{Ni}$ (100) surface. Wang and Lua [98] were carried out kinetic studies on methane decomposition over $\mathrm{Ni}$ catalyst and found that the average reaction order and activation energy for the methane decomposition over the unsupported nickel was 0.63 and $65.4 \mathrm{~kJ} / \mathrm{mol}$, close to those previously published values furnished in Table 2. The wide range of reported activation energies may be due to many factors, including the difficulty of collecting true kinetic data and the highly dynamic characteristics of the process [100]. Wang and Lua [98] found that, when $P_{\mathrm{CH}_{4}}$ was increased from $0.2 \mathrm{~atm}$ to $1 \mathrm{~atm}$, the hydrogen formation rate significantly increased but the catalyst activity decreased. The faster deactivation of the catalyst was subjected to a higher reaction temperature, which accelerated methane dissociation and increased the diffusion rate. Generally, increasing reaction temperature increases methane dissociation due to the endothermic nature of the reaction while at the same time the diffusion rate also increases accordingly. In the case of $2 \mathrm{Ni}-1 \mathrm{Co}-1 \mathrm{Cu}$, a faster carbon diffusion rate at a higher temperature would probably speed up the

Table 5

Comparative study of influence of experimental parameters.

\begin{tabular}{|c|c|c|c|c|c|c|c|c|c|c|}
\hline \multirow[t]{2}{*}{ Catalyst } & \multicolumn{3}{|c|}{ Operating conditions } & \multicolumn{2}{|c|}{ Maximum } & \multirow[t]{2}{*}{$t_{\max }$} & \multirow{2}{*}{$\begin{array}{l}\mathrm{CH}_{4} \\
\text { At time ' } t \text { ' }\end{array}$} & \multirow[t]{2}{*}{$\mathrm{H}_{2}$} & \multirow[t]{2}{*}{$t$} & \multirow[t]{2}{*}{ Ref. } \\
\hline & $T$ & $F$ & $w$ & $\begin{array}{l}\mathrm{CH}_{4} \\
\text { At } t_{\max }\end{array}$ & $\mathrm{H}_{2}$ & & & & & \\
\hline \multirow[t]{5}{*}{ DCC-N103(P) (CB) } & 850 & $15,000^{\mathrm{a}}$ & 0.1 & 2 & - & 0.1 & 1 & - & 2 & [146] \\
\hline & 870 & & & 4 & - & 0.1 & 2 & - & 2 & \\
\hline & 900 & & & 5 & - & 0.25 & 3 & - & 2 & \\
\hline & 925 & & & 5 & - & 0.1 & 5 & - & 2 & \\
\hline & 950 & & & 13 & - & 0.1 & 7 & - & 2 & \\
\hline \multirow{3}{*}{ CG Norit (CB) } & 850 & $20^{\mathrm{b}}$ & - & - & 72 & 0.1 & - & 30 & 4 & [138] \\
\hline & & $50^{\mathrm{b}}$ & - & - & 62 & 0.1 & - & 17 & 4 & \\
\hline & & $100^{\mathrm{b}}$ & - & - & 48 & 0.1 & - & 8 & 4 & \\
\hline \multirow[t]{2}{*}{ Fluka 05120} & 850 & $20^{\mathrm{b}}$ & - & - & 60 & 0.1 & - & 38 & 4 & \\
\hline & & $50^{\mathrm{b}}$ & - & - & 51 & 0.1 & - & 28 & 4 & \\
\hline \multirow{3}{*}{ NORIT CG (commercial AC) } & 950 & $600^{a}$ & 2 & - & 94 & 1.1 & - & 38 & 4 & [125] \\
\hline & 900 & & & - & 85 & 0.6 & - & 30 & 4 & \\
\hline & 850 & & & - & 68 & 0.5 & - & 30 & 4 & \\
\hline \multirow[t]{4}{*}{ Xiaolongtan char } & 1000 & $200^{\mathrm{b}}$ & 10 & 96 & 90 & 0 & 19 & 18 & 2 & [155] \\
\hline & 850 & & & 69 & 48 & 0 & 20 & 10 & 2 & \\
\hline & 700 & & & 29 & 20 & 0.1 & 9 & 8 & 2 & \\
\hline & 600 & & & 10 & 9 & 0.1 & 5 & 5 & 2 & \\
\hline \multirow[t]{12}{*}{ ACPS } & 850 & $1764 \mathrm{~h}^{-1}$ & 20 & 49.8 & 47.9 & 0 & - & - & - & [135] \\
\hline & 850 & $882 \mathrm{~h}^{-1}$ & 40 & 34.9 & 62.5 & 0 & - & - & - & \\
\hline & 850 & $441 \mathrm{~h}^{-1}$ & 80 & 21.2 & 77 & 0 & - & - & - & \\
\hline & 850 & $294 \mathrm{~h}^{-1}$ & 120 & 16.7 & 81.6 & 0 & - & - & - & \\
\hline & 850 & $294 \mathrm{~h}^{-1}$ & 40 & 13.2 & 83.1 & 0 & - & - & - & \\
\hline & 850 & $441 \mathrm{~h}^{-1}$ & 40 & 22 & 78.3 & 0 & - & _- & - & \\
\hline & 850 & $882 \mathrm{~h}^{-1}$ & 40 & 34.9 & 62.5 & 0 & - & - & - & \\
\hline & 850 & $1764 h^{-1}$ & 40 & 41.5 & 57.9 & 0 & - & - & - & \\
\hline & 850 & $882 \mathrm{~h}^{-1}$ & 40 & 34.9 & 62.5 & 0 & - & - & - & \\
\hline & 825 & $882 \mathrm{~h}^{-1}$ & 40 & 37.6 & 60.9 & 0 & - & - & - & \\
\hline & 800 & $882 \mathrm{~h}^{-1}$ & 40 & 48.7 & 50.9 & 0 & - & _- & - & \\
\hline & 775 & $882 \mathrm{~h}^{-1}$ & 40 & 59.5 & 39.1 & 0 & - & - & - & \\
\hline \multirow[t]{4}{*}{$\mathrm{Ni}-\mathrm{AC}$} & 550 & $50^{\mathrm{b}}$ & 0.20 & 4 & - & 0 & 0 & - & 1 & [105] \\
\hline & 650 & & & 6 & - & 0 & 1 & - & 2 & \\
\hline & 750 & & & 13 & - & 0 & 2.5 & - & 2 & \\
\hline & 850 & & & 27 & - & 0 & 2.5 & - & 1 & \\
\hline \multirow[t]{3}{*}{ BP1300 (CB) } & 850 & $36 \mathrm{~h}^{-1}$ & - & - & 92 & 0 & - & 46 & 6.5 & [139] \\
\hline & & $72 \mathrm{~h}^{-1}$ & - & - & 70 & 0 & - & 26 & 6.5 & \\
\hline & & $144 \mathrm{~h}^{-1}$ & - & - & 41 & 0 & - & 15 & 6.5 & \\
\hline \multirow[t]{3}{*}{ BP2000 (CB) } & 850 & $36 \mathrm{~h}^{-1}$ & - & - & 59 & 0 & - & 28 & 6.5 & \\
\hline & & $72 \mathrm{~h}^{-1}$ & - & - & 35 & 0 & - & 20 & 6.5 & \\
\hline & & $144 \mathrm{~h}^{-1}$ & - & - & 18 & 0 & - & 11 & 6.5 & \\
\hline \multirow[t]{3}{*}{ BP2000 (CB) } & 950 & $144 \mathrm{~h}^{-1}$ & - & - & 78 & 0 & - & 62 & 6.5 & \\
\hline & 900 & & - & - & 59 & 0 & - & 38 & 6.5 & \\
\hline & 850 & & - & - & 18 & 0 & - & 11 & 6.5 & \\
\hline
\end{tabular}

$\left(T\right.$, temperature $\left({ }^{\circ} \mathrm{C}\right) ; F$, flow rate $\left({ }^{\mathrm{a}} \mathrm{mL} /\left(\mathrm{g}_{\mathrm{cat}} \mathrm{h}\right){ }^{\mathrm{b}} \mathrm{mL} / \mathrm{min}\right.$, unless other units are stated); $W$, catalyst mass $(\mathrm{g}) ;$ Conversion $(\%) ; t_{\max }$ time at which maximum methane conversion or hydrogen production occur $(\mathrm{h}) ; t$, time $(\mathrm{h}) ;-$, not mentioned in the original paper).

\section{Link to Full-Text Articles :}

http://www.sciencedirect.com/science/article/pii/S1364032114010776 